\title{
A ESCRITA DA INFÂNCIA EM GRACILIANO RAMOS E MURILO MENDES
}

\author{
Alinnie Oliveira Andrade Santos* \\ Universidade Federal do Pará
}

\begin{abstract}
Resumo: Desde o século XIX, os escritores brasileiros de textos literários dedicaram-se a registrar os eventos de sua vida em autobiografias. Essa prática se intensificou na primeira metade do século XX, período em que diversos autores modernistas escreveram suas memórias. Entre esses escritores, destacam-se Graciliano Ramos (1892-1953) e Murilo Mendes (1901-1975), os quais relataram os acontecimentos dos seus primeiros anos de vida em Infância (1945) e A Idade do Serrote (1969), respectivamente, dando ênfase à relação deles com os pais, as experiências de alfabetização e aprendizagem da leitura, como também a sua formação como leitor. Este trabalho, portanto, tem por objetivo analisar comparativamente essas duas obras, observando como esses autores fizeram uso dos elementos recorrentes na autobiografia clássica, assim como verificar a imagem da infância que esses autobiógrafos elaboraram, tendo em vista os estudos realizados por Silvia Molloy (2003) e Jürgen Straub (2009), sobre a reconstrução do passado em textos autobiográficos.
\end{abstract}

Palavras-chave: Infância. Elaboração do Passado. Autobiografia

\section{Introdução}

O homem do século XVIII, na Europa, passou a escrever suas memórias, cartas e diários, objetivando revelar em tais escritos o motivo de suas ações, descrever seus sentimentos, bem como suas opiniões, para si mesmo e para os demais membros da sociedade. Tal prática ganhou força e intensidade nos séculos posteriores não somente no continente europeu, como também em outros lugares do mundo. 
No Brasil, por exemplo, esse gênero se popularizou e muitos escritores de textos literários, desde o século XIX até o presente momento, passaram a relatar os acontecimentos de sua vida em autobiografias, como é o caso dos escritores modernistas Graciliano Ramos e Murilo Mendes, os quais publicaram, respectivamente, as obras Infância (1945) e A Idade do Serrote (1969).

Esse trabalho, portanto, objetiva analisar as referidas autobiografias, observando a imagem da infância reconstruída por seus autobiógrafos, como caracterizam os anos iniciais de sua vida, levando em consideração para o estudo os elementos recorrentes nos dois textos memorialísticos estudados. Além disso, no final do texto, fazemos uma ligeira comparação entre as duas obras, evidenciando semelhanças entre elas que não fazem parte da retórica clássica da autobiografia.

\section{A Elaboração do Passado na Autobiografia}

O século XVI viu os primeiros passos da ascensão da individualidade do sujeito. $\mathrm{O}$ surgimento da cultura renascentista, a desintegração do sistema feudal, que gerou mudanças sócio-políticas e econômicas, a secularização do pensamento e a expansão dos limites geográficos e culturais foram alguns dos fatores que levaram o homem dessa época a fazer uso da escrita autobiográfica na tentativa de se autoafirmar diante de tantas modificações.

Assim, o homem quinhentista queria deixar um registro de si, uma marca para que não fosse esquecido pela posteridade e então, buscou na construção de textos autobiográficos uma forma de fixar a própria imagem. Dessa forma, a autobiografia servia como uma espécie de alicerce para o sujeito.

É nesse período que Michel de Montaigne escreveu os seus Ensaios. Essa obra não é considerada uma autobiografia no sentido tradicional, pois por sua fragmentação e descontinuidade, tem uma proximidade maior com a escrita do diário, além de não apresentar uma síntese biográfica. Os Ensaios de Montaigne ocupam um lugar periférico na tradição do gênero autobiográfico por subverter as reivindicações do sujeito, contrariando a ideia de um sujeito uno, muito forte na época. Esse caráter descontínuo de seus escritos aponta para o momento que ele estava vivendo, de formação de uma subjetividade.

Essa situação - de construção de uma individualidade - se intensificou nos dois séculos seguintes. O Estado Absolutista interveio, passando a controlar de forma rígida o comportamento social, o que fez com que ocorresse uma divisão entre a esfera pública e a 
privada. É nesse espaço entre ambas as esferas que a subjetividade moderna pôde se desenvolver.

Nesse momento, a burguesia emergente, que estava se libertando do controle do Estado Absolutista, encontrou no espaço privado um campo para se fortalecer e defender valores e privilégios diferenciados da aristocracia, tais como: a ideia de que é livre da autoridade da realeza, de que os seus laços pessoais se firmam pelo sentimento e afeição, além de uma cultura própria, como uma ideologia de sustentação dessa nova classe.

Sendo assim, o homem burguês se vê como um sujeito autônomo capaz de se relacionar afetivamente com os outros sujeitos e de representar a si mesmo, configurando novas formas de interação social, como a carta e o diário que serviam para extravasar os afetos e sentimentos em um diálogo com o outro e consigo mesmo.

Dessa forma, o espaço de expressão da esfera privada sofre um processo de abertura, não somente com as cartas e diários, mas também em função do aumento de lugares públicos que serviam para expressar tal subjetividade, como: cafés, salões literários e a imprensa, nos quais se podiam trocar opiniões, juízos de gosto e preferências, práticas até então realizadas somente na intimidade.

Assim, o espaço social - aspecto essencial da experiência moderna - entra em choque com a vida privada, tornando-se uma ameaça a esta. Conhecedor desse ambiente público, o filósofo francês Jean-Jacques Rousseau foi um dos primeiros a enunciar o surgimento desse conflito:

\footnotetext{
Se a esfera privada que diz respeito ao individual, ao íntimo, ao ser próprio do indivíduo, constitui o âmbito da ação, a esfera social - com a sua exigência de padronização, objetivação, normatização e administração de tudo - passa a ser, por antítese, a esfera não da ação, mas do comportamento; o conformismo e a homogeneização próprios ao espaço social, como percebeu Rousseau, corrompem, deterioram, anulam a autenticidade, a espontaneidade, enfim, aquilo que há de mais próprio ao momento mesmo da ação que "brota da pura espontaneidade interior do indivíduo.” (DUQUE-ESTRADA, 2009. p. 139)
}

As Confissões escritas por Rousseau se configuram como uma reação à padronização e homogeneização dos indivíduos, bem como a primeira defesa a invasão do social. Essa obra é considerada como a gênese do texto autobiográfico, pois apresenta os princípios fundamentais da autobiografia clássica. Nesse texto, encontramos uma unidade sintética que agrupa e organiza todos os acontecimentos do passado até o momento presente. Assim, todos os eventos da vida do autor da mais variada categoria são integrados por meio da narrativa em uma totalidade de sentido. 
Para Leonor Arfuch (2010. p. 51), o objetivo de Rousseau era, por meio de uma aparente sinceridade expressa "numa nova retórica do íntimo", despertar a admiração cúmplice dos seus leitores. No entanto, esses leitores trataram as Confissões como um texto literário, visto que os procedimentos de que Rousseau fez uso em seu texto se assemelhavam com os utilizados pelos autores de obras literárias.

A prática de se escrever autobiografias não ficou restrita somente ao século XVIII e à Europa, ela se estendeu e se intensificou nos séculos seguintes e em outros lugares do mundo, como na América Latina. Os textos autobiográficos escritos após as Confissões ora seguem, ora transgridem os procedimentos narrativos utilizados por Rousseau, renovando constantemente a retórica da autobiografia.

Na concepção de Silvia Molloy (2003. p. 18), a autobiografia, de modo geral, é uma história contada pela segunda vez, isto é uma re-presentação, já que a própria vida é uma construção narrativa. Sendo assim, o texto autobiográfico não está relacionado somente com os acontecimentos que ocorreram na vida do autobiógrafo, mas sim como esses eventos estão armazenados na memória e como são articulados no momento de sua verbalização.

Dessa forma, tais fatos se modificam continuamente, transformando o passado em um produto continuamente inacabado, uma vez que depende tanto da visão que o sujeito tem do presente, como também do que ele espera para o seu futuro. Em outras palavras, não apenas o passado é capaz de determinar o presente e o futuro, podemos afirmar que estes são determinantes também para a construção do passado:

\begin{abstract}
A memória autobiográfica não é um dispositivo de armazenamento como uma câmera de vídeo, no qual o passado é preservado como era originalmente. Da mesma forma, recordar não é uma mera recuperação de dados armazenados. (...). Nosso passado, assim como nosso presente e nosso futuro, não consiste apenas de eventos que podem ser gravados tecnicamente com um gravador ou com uma câmera de vídeo. O passado narrado na vida de um ser humano não pode ser transmitido de forma técnica. É um produto continuamente inacabado e, portanto, cambiante da memória e sua recuperação, do qual são partes constitutivas a seletividade, a relevância, a estruturação simbólica e outras características de atos transmitidos de forma hermenêutica. (STRAUB, 2009. p. 84-85)
\end{abstract}

Em função dessa característica mutável do tempo passado, o autobiógrafo faz uso do período atual como modelo para se autorreferenciar. Ou seja, sua visão sobre o passado está condicionada ao momento do presente da escrita para a construção da imagem que ele quer apresentar ao leitor: "O passado evocado molda-se por uma autoimagem sustentada no presente - a imagem que o autobiógrafo tem, aquela que ele ou ela deseja projetar ou aquela que o público pede.”( MOLLOY. 2003. p, 22). 
Um outro aspecto que deve ser considerado com relação ao texto autobiográfico, sobretudo os escritos na América Latina, é a recorrência de trechos de textos verdadeiros de outros autores, os quais são aproveitados pelo autobiógrafo como uma demonstração daquilo que está armazenado na sua memória e como um instrumento para efetivar a sua autorrrepresentação. Muitas vezes o escritor se apropria do arquivo europeu, conforme afirma Molloy (2003. p, 20), para retirar esses fragmentos textuais, ora meramente se apropriando dos elementos desse arquivo, ora desviando-se dele.

No Brasil, muitos escritores modernistas dedicaram-se a escrever suas memórias, elaborando o seu passado e construindo uma imagem de si para o seu público leitor, tais como: Manuel Bandeira que publicou Itinerário de Pasárgada (1954); Oswald de Andrade que escreveu Um Homem sem Profissão (1954); José Lins do Rêgo, que lançou Meus Verdes Anos (1956); Augusto Frederico Schmidt que publicou As Florestas (1959) e Cyro dos Anjos que escreveu A Menina do Sobrado (1979).

Muitos desses autores reservaram páginas consideráveis de suas memórias para construir uma imagem da sua infância, como é o caso de Infância (1945), escrita por Graciliano Ramos e A Idade do Serrote (1968), de autoria de Murilo Mendes.

\section{"Aos nove anos eu era quase analfabeto": a elaboração do passado em Graciliano Ramos}

No seu livro de memórias sobre os anos na prisão, Memórias do Cárcere (1953) o escritor nordestino Graciliano Ramos declara a intenção que tinha de escrever um livro sobre a sua infância, pois tinha o interesse de falar "a respeito da bárbara educação nordestina.”. Vemos então, segundo Eliane Zagury (1982, p.119), o processo de composição que resultou na obra Infância. O referido livro é o último publicado em vida por Graciliano Ramos, no qual, como o próprio título já enuncia, o autor relata, com certa linearidade, desde os primeiros anos de sua infância até o momento inicial da sua adolescência, enfatizando que os acontecimentos de sua vida contribuíram para que se tornasse escritor:

Em uma época avançada de sua vida, Graciliano Ramos conta como, desde a sua infância, as diferentes experiências do seu processo de aprendizagem contribuíram para formá-lo como intelectual e escritor. Trata-se, portanto, de uma verdadeira construção, tanto no sentido de que os atos e eventos do passado foram selecionados e dizem respeito a sua importância para o presente, como no sentido de que é esse presente que outorga a esses eventos e atos a sua significação. Isto é, não é o passado que explica o presente, senão ao contrário; é o presente que nos permite entender e explicar o passado. Assim, Graciliano Ramos, escreve, no final de sua vida, um texto autobiográfico no qual a infância se apresenta como a época decisiva 
na qual se formaram as convicções éticas, que marcaram a sua existência como escritor, provocaram sua resistência e fundaram seu ateísmo. (NITSCHACK, 2009, p. 237).

Para Antonio Candido, a prosa de Graciliano Ramos passa da ficção para a confissão, pois muitas das pessoas e situações de Infância podem ser encontradas no seu livro Angústia (1936). Sua autobiografia, então, para o crítico, é o desdobramento coerente e necessário da sua obra:

\begin{abstract}
Assim parece que Angústia contém muito de Graciliano Ramos, tanto no plano consciente (pormenores biográficos) quanto no inconsciente (tendências profundas, frustrações), representando a sua projeção pessoal até aí mais completa no plano da arte. Ele não é Luís da Silva, está claro, mas Luís da Silva é um pouco o resultado do muito que, nele, foi pisado e reprimido. E representa na sua obra o ponto extremo da ficção; o máximo obtido na conciliação do desejo de desvendar-se com a tendência de reprimir-se, que deixará brevemente de lado a fim de se lançar na confissão pura e simples.(CANDIDO, 2006, p. 61-62)
\end{abstract}

Logo no início de suas memórias, Graciliano, ao relatar sua primeira lembrança, apresenta qual vai ser um dos temas recorrentes de sua autobiografia: o contato com as palavras e a busca por conhecer o significado delas. Ao se lembrar do vaso de louça vidrada cheio de pitombas, ele evidencia a sua primeira relação com as palavras, pois usava o termo "pitombas" para se referir a todos os objetos esféricos.

A lembrança seguinte do menino é a de uma aula de alfabetização em uma escola primária da roça:

A sala estava cheia de gente. Um velho de barbas longas dominava uma negra mesa, e diversos meninos, em bancos sem encostos, seguravam folhas de papel e esgoelavam-se

-- um $b \operatorname{com} a-b, a: b a ; \operatorname{um} b \operatorname{com} e-b, e: b e$.

Assim por diante, até $u$. Em escolas primárias da roça ouvi cantarem a soletração de várias maneiras. (...). Em pé, junto ao barbado, uma grande moça, que para o futuro adquiriu os traços de minha irmã natural, tinha nas mãos um folheto e gemia:

--A, B, C, D, E. (RAMOS, 1975, p.10).

É interessante ressaltar que antes de qualquer descrição dos pais, irmãos, ou da casa em que morava - práticas comuns a retórica da autobiografia - o autor aponta para o interesse do menino pelas palavras, insinuando a importância que elas viriam a ter no seu futuro como escritor, conforme salienta Horst Nitschack:

Esta lembrança aparece como lembrança originária na qual já se decide o seu futuro; a fascinação pelas letras prepara sua carreira de escritor e, assim, ele constrói uma linha reta, uma coerência necessária entre a sua infância e a vida atual do escritor: é significativo que esta lembrança das letras seja mais antiga do que a lembrança da irmã, que só mais trade será identificada como tal. Antes de poder identificar a própria irmã, antes das imagens dos próprios pais, surgem na memória 
(reconstruída) as letras. Essas letras pelas quais vai se definir, no futuro, sua relação com o mundo. ( NITSCHACK, 2009. p. 247).

O fascínio pelas palavras continua no decorrer do primeiro capítulo, com a curiosidade do menino em saber o significado da palavra grajau: “Grajau? Que seria grajau? Tornei a mergulhar no sono, um sono extenso." (RAMOS,1975. p. 11). Esse detalhe é um artifício do texto para se enfatizar o interesse do menino pelas palavras.

Em seguida, é apresentada uma descrição da família, pai e mãe são identificados como "entidades próximas e dominadoras". Em todo o livro, os pais não são expostos como protetores ou amáveis, que sempre amparam o filho, mas como figuras de autoridade, as quais o menino obedecia por medo:

Nesse tempo meu pai e minha mãe já estavam caracterizados: um homem sério, de
testa larga, uma das mais belas testas que já vi, dentes fortes, queixo rijo, fala
tremenda; uma senhora enfezada, agressiva, ranzinza, sempre a mexer-se, bossas na
cabeça mal protegida por um cabelinho ralo, boca má, olhos maus que em
momentos de cólera se inflamavam com um brilho de loucura. Esses dois entes
difíceis ajustavam-se.( RAMOS,1975. p. 16.)

Um exemplo interessante da forma como o pai lhe tratava é o capítulo intitulado " $\mathrm{O}$ Cinturão", em que o escritor se recorda de uma das vezes que o menino levou uma surra, o que para ele foi o seu primeiro contato com a justiça. Nesse capítulo, o pai do menino estava dormindo em uma rede na sala. Ao acordar mal-humorado, despertou o pavor da criança, que se encolheu em um canto da sala. O pai insistia, aos berros, em querer saber onde estava o seu cinturão, desconhecido pelo menino. $\mathrm{O}$ autor descreve, então, o medo que se apoderou do pequeno que esperou inutilmente que alguém aparecesse e o livrasse do chicote de seu pai. $\mathrm{O}$ menino, por fim, acabou sendo castigado:

Junto de mim, um homem furioso, segurando-me um braço, açoitando-me. (...). Certamente o meu choro, os saltos, as tentativas para rodopiar na sala como carrapeta, eram menos um sinal de dor que a explosão do medo reprimido. Estivera sem bulir, quase sem respirar. Agora esvaziava os pulmões, movia-me num desespero.

O suplício durou bastante, mas, por muito prolongado que tenha sido, não igualava a mortificação da fase preparatória: o olho duro a magnetizar-me, os gestos ameaçadores, a voz rouca a mastigar uma interrogação incompreensível. (RAMOS, 1975. p. 34-35)

No entanto, o menino era inocente dessa acusação e foi açoitado injustamente. O cinturão estava o tempo todo na rede em que o pai dormira. Apesar de descobrir a injustiça, o pai apenas se afastou do filho. No final do capítulo, ele apresenta a forma como via o pai: "cruel e forte, soprando, espumando", além de como ele próprio se via diante da figura 
paterna: "miúdo e insignificante", demonstrando assim que seu contato com o pai era regido pelo medo.

A relação com a mãe é descrita de maneira semelhante, pois ela também não tratava o filho de forma amorosa, tanto que o menino estranha quando, ao ler uma notícia sobre o suposto fim do mundo, a mãe abraça-o aos prantos, com umas "carícias ásperas". Quando o menino ficou doente, a própria mãe pôs apelidos nele: "Minha mãe tinha a franqueza de manifestar-me viva antipatia. Dava-me dois apelidos: bezerro-encourado e cabra-cega." (RAMOS, 1975. p. 136).

Há de se salientar os termos que o autor usa para se referir a ela, tais como: "pobre mulher", "fraca", que tinha "mãos ossudas, inofensivas" e "peito magro", que nos ajudam a entender a visão do autor no presente da escrita sobre a figura materna, chegando até a desculpá-la por seus atos contra o menino. Apesar da pouca diferença de idade entre eles, cerca de quinze anos, eram raros os momentos de trégua, em que podiam conversar tranquilamente, cabendo ao filho saber como lidar com as oscilações de humor da mãe:

\begin{abstract}
As vezes minha mãe perdia as arestas e a dureza, animava-se, quase se embelezava, catorze ou quinze anos mais moço que ela, habituei-me, nessas tréguas curtas e valiosas, a julgá-la criança, companheira de gênio variável, que era necessário tratar cautelosamente. Sucedia desprecatar-me e enfadá-la. Os catorze ou quinze anos surgiam entre nós, alargavam-se de chofre e causavam-me desgosto. (RAMOS, 1975. p. 75).
\end{abstract}

Assim podemos perceber que, com relação aos seus pais, Graciliano não faz uso de imagens usuais da infância, pois seu relato vai de encontro à ideia comum de que os pais, nos primeiros anos de vida de um filho, dedicam-se a cuidar da dele, ofertando cuidado e proteção desmedidos, visando o bem-estar da criança. Pelo contrário, os pais do menino Graciliano são retratados como autoritários e sem ter a intenção de demonstrar afeto ao filho.

Além de descrever a relação com os pais, Graciliano também relata a curiosidade recorrente do menino, que sempre queria descobrir o significado das palavras, entender como funcionavam as coisas na fazenda de seu pai, ou posteriormente na loja. No entanto, sua curiosidade nunca era saciada, pois ninguém tinha o interesse de lhe dar as respostas que tanto o menino queria:

Vivia a surpreender-me. E as surpresas se multiplicavam. Amaro e José Baía, armados de facões estariam enchendo cestos com pedaços de mandacaru? Os sentidos me diziam que sim, mas isto discordava dos serviços comuns. Tentava esclarecer-me, largava uma interrogação maluca. Não indagava o motivo de se encherem os cestos, perguntava se eles realmente se enchiam. Caso me confirmassem a observação, eu continuaria a importunar os empregados, inteirarme-ia de que aquilo era alimento para os animais. Não me ligavam importância. Amaro fungava, resmungava, franzia a cara cabeluda; José Baía pilheriava. Por quê? 
Não era tão fácil asseverarem que estavam cortando mandacaru nos cestos? Eu necessitava uma autoridade, um apoio. Desconfiava da coisa próxima, vista, ouvida, pegada, mas em geral admitia sem esforço o que me contavam. (RAMOS, 1975. p. 28).

Algumas vezes essa sua curiosidade resultava em punição, como no caso do significado da palavra inferno. Ao indagar sua mãe e receber uma resposta insatisfatória, pergunta se ela ou os padres já estiveram nesse lugar, o que causou a indignação da mãe, aplicando no menino várias chineladas.

Os primeiros contatos do menino com a aprendizagem da leitura são descritos como sendo um desastre. Seu pai tentava ensiná-lo, mas de forma incompreensível para uma criança, o que fez com que o menino não sentisse interesse em aprender a ler.

Esse desinteresse persiste ao entrar na escola, pois com um ensino de má qualidade, com uma metodologia que não atraía a atenção do aluno e com o uso de livros didáticos totalmente distantes do contexto vivido pela criança, como os do Barão de Macaúbas, fizeram com que o menino Graciliano mesmo aos nove anos de idade, não soubesse ler:

O lugar de estudo era isso. Os alunos se imobilizavam nos bancos: cinco horas de
suplício, uma crucificação. Certo dia vi moscas na cara de um, roendo o canto do
olho, entrando no olho. E o olho sem se mexer, como se o menino estivesse morto.
Não há prisão pior que uma escola primária do interior. A imobilidade e a
insensibilidade me aterraram. Abandonei os cadernos e as auréolas, não deixei que
as moscas me comessem. Assim, aos nove anos ainda não sabia ler. (RAMOS, 1975 .
p. 195).

Dessa forma, o autor aproveita para fazer uma crítica ao método de ensino aplicado nas escolas primárias do interior da época, os quais, pois usando sua própria vivência nessas escolas, ele mostra a ineficácia desse tipo de educação, a qual não consegue atingir seus objetivos de ensinar o aluno a ler e escrever, já que este aprende com muitas deficiências.

A crítica continua ao apresentar que o interesse do menino pela leitura é despertado bem distante do espaço escolar: começa a ler histórias sozinho depois de duas noites de leitura com o pai e, em busca de novos livros, dirige-se a casa de Jerônimo Barreto, tabelião da cidade, que consentiu em emprestar ao menino vários dos livros de sua biblioteca, o qual ocupa o lugar de mentor ou guia do menino no mundo da leitura, algo comum em autobiografias de escritores. Em virtude das leituras que fazia, o menino passa por transformações no seu comportamento, hábitos, linguagem e postura, tanto em casa, como na escola. Ele começava a viver a literatura.

Durante todo o livro, se misturam as perspectivas da criança e do adulto no presente da escrita, por exemplo, ao encerrar suas considerações sobre o Padre João Inácio, apresenta duas visões acerca do religioso: "Padre João Inácio não sabia falar conosco, sorrir, brincar - e 
as nossas almas se fecharam para ele. Em Padre João Inácio, homens de ações admiráveis, só percebíamos dureza" (RAMOS, 1975. p. 67). Quando diz que só via dureza no padre, são as impressões do menino, quando menciona que o padre era um homem de ações admiráveis, é o adulto no presente da escrita.

$\mathrm{Na}$ tentativa de elaborar o passado vivido quando menino, o autor relata alguns momentos em que a criança não consegue distinguir ou compreender o que, ou quem era bom ou mau. Isso ocorre com o personagem Fernando, tido pelo menino como um homem mal e cruel, que o amedronta, mas que, em um determinado momento tem um ato de bondade ao envergar os pregos presos em uma das tábuas dos caixões da loja, pensando no risco que uma criança descalça corria podendo pisar em tais pregos:

Eu não acreditava nos meus olhos nem acreditava nos meus ouvidos. Então Fernando não era mau? Pensei num milagre. Julguei ter sido injusto. Fernando, o monstro, semelhante a Nero, receava que as crianças ferissem os pés. Esqueci as torpezas cochichadas, condenei o dicionário vermelho que tinha bandeiras e retratos. Talvez Nero, o pior dos seres, envergasse os pregos que poderiam furar os pés das crianças. (RAMOS, 1975. p. 214).

Tal ato de Fernando confundiu o menino, que, muito pequeno, não conseguia ainda compreender o binarismo das situações, não podia entender as diferentes atitudes que uma pessoa poderia ter.

Como podemos perceber, a autobiografia de Graciliano Ramos apresenta a imagem de um indivíduo que, na infância, sofreu uma educação repressora dos pais, recebeu um ensino precário na escola, mas que mesmo assim teve a possibilidade de ter acesso a livros e assim, apesar de todas as dificuldades que enfrentou pôde interessar-se por Literatura, fato que contribuiu para que ele, anos mais tarde, viesse a se tornar um autor de textos literários.

Todos esses aspectos descritos na elaboração do passado do escritor nordestino apontam para o homem que ele veio a se tornar no presente. Ou seja, esses eventos da infância foram relatados nesse livro com a intenção de evidenciar para quem tivesse contato com essa obra, que tais acontecimentos colaboraram para a formação de Graciliano como o intelectual e escritor que se tornou.

\section{"Só gosto de ver moça e ler poesia": a infância reconstituída de Murilo Mendes}

O poeta Murilo Mendes autor de poemas que remetem à fantasia, ao surrealismo à religiosidade, também escreveu algumas obras em prosa, dentre as quais destacamos A Idade 
do Serrote (1969), na qual relata suas memórias da sua infância e adolescência vividas em sua cidade natal Juiz de Fora, em Minas Gerais.

Para Antonio Candido (1987), apesar de escrita em prosa, essa obra, por ter um “ímpeto transfigurador” se aproxima da poesia. Além disso, para o crítico, Murilo Mendes é um poeta que sempre escreveu poesia, até quando escrevia em prosa.

Candido, em seguida, aponta três aspectos do texto memorialístico do escritor mineiro. O primeiro diz respeito à variação de tema que ocorre no decorrer das memórias, fazendo uso de um duplo movimento de composição: no primeiro momento fixa um tema e o trabalha descrevendo toda a sua particularidade, depois o desdobra em todos os significados possíveis e em variações intermináveis, multiplicando o tema e atribuindo a ele toque de intemporalidade.

O segundo aspecto se refere à mudança recorrente de estilo. "Longe de recorrer a um discurso homogêneo, melodicamente desenvolvido, Murilo ajusta-o estruturalmente ao tema e à circunstância, quebrando a singularidade dos fatos e dando-lhes uma ampla possibilidade de significar.”(CANDIDO, 1987, p. 58).

O terceiro e último aspecto elencado por Candido é uso sistemático do insólito, no formato ou de excentricidade, aberração da norma ou loucura, o que faz com que, na obra, o que é comum seja tratado como extraordinário e o que de fato é extraordinário seja considerado comum.

Durante todo o seu texto, Murilo Mendes transgride a retórica da autobiografia, acrescentando autobiografemas novos, deixando de lado os já clássicos, ou modificando-os, em função da intensa fragmentação com a qual constrói o seu texto.

Um exemplo disso encontra-se nas páginas iniciais de A Idade do Serrote, nas quais não se encontra a primeira lembrança do menino, um autobiografema básico, mas somente registros fragmentários de fatos, circunstâncias e pessoas que estarão desenvolvidas ao longo do texto. Dessa forma, esses fragmentos condensam o que virá no livro, pois serão desdobrados nos capítulos seguintes.

Nesse primeiro capítulo extremamente fragmentado, encontramos uma espécie de romance familiar, uma breve descrição dos seus pais:

Meu pai, grande coração comunicante. Servidor público. Do próximo. Escrivão de registro de títulos e hipotecas da cidade de Juiz de Fora. Minha mãe, afeiçoada ao canto e ao piano, morre de parto com vinte e oito anos. Torna-se constelação. Minha segunda mãe, Maria José, grande dama da cozinha e salão, resume a ternura brasileira. Risquei do vocabulário a palavra madrasta. (MENDES, 2003, p. 25). 
Vemos, então, a descrição de uma família bem diferente daquela apresentada na biografia de Graciliano Ramos, pois o menino Murilo, apesar de criado pela madrasta, vive em uma atmosfera de ternura, o que faz com que ele sinta que ela é também sua mãe.

Outras descrições do pai são feitas pelo autor no decorrer da autobiografia. Ao passear com o pai pela Rua Direita, caracteriza-o como "popularíssimo", "comunicável” e que "fala a todos com afabilidade" (MENDES, 2003. p. 47). Além disso, conta um pouco a história de vida do seu pai, enfatizando o lado humanista deste:

\footnotetext{
Meu pai deixa cedo a fazendola familiar em Santo Antônio da Pedra, no Oeste de Minas. Impele-o entre menino e adolescente o desejo de ajudar meu avô que por motivo de saúde descuidara-se de seus bens; interrompendo os estudos emigra para a Zona da Mata. Possuindo inteligência intuitiva, força de vontade, amor ao trabalho e o dom da comunicação, dentro de poucos anos fixa-se, funcionário público, em Juiz de Fora, casando-se (duas vezes) numa das mais antigas famílias do Brasil. Desenvolvendo suas qualidades de simpatia humana e senso de solidariedade com o próximo, torna-se um personagem querido, árbitro de questões complexas, encarregado muitas vezes de sabotar certas obras subterrâneas do príncipe das trevas ou de seus acólitos. (MENDES, 2003. p, 172).
}

Murilo também afirma que o maior legado que seu pai the deixou foi a religião católica, que o ensinou ainda menino, com mais eficácia que muitos padres. Essa caracterização do pai nos mostra que o poeta mineiro queria apontar somente aspectos positivos de sua família, evidenciando apenas as qualidades e virtudes de seus pais.

Um outro aspecto que o escritor procura enfatizar em suas memórias é a sua formação como leitor, mencionando quem foram os seus guias nos caminhos da literatura. $\mathrm{O}$ primeiro deles foi Belmiro Braga que o auxilia não apenas com a leitura, mas também com a produção dos seus primeiros versos:

\footnotetext{
Amigo de meu pai, tendo eu sete anos voluntariamente me ensina a rimar e metrificar, mais tarde me abre a caverna da sua biblioteca onde durante mil e uma tardes descubro Bocage, Antônio Nobre, Cesário Verde, Fialho de Almeida, Eça de Queirós, vingando-me dos tratados de FTD, Raposo Botelho, Conrado Cruz e dos chatíssimos livros de Samuel Smiles; passando sempre debaixo das nossas janelas me pergunta o que estou lendo agora, corrige meus primeiros versos engatinhando, sugere-me temas, com exemplar caligrafia capaz de transfigurar o pior texto escreve quadras que recitarei nos saraus literários do Colégio Lucindo Filho ou da casa de Sinhá Leonor. (MENDES, 2003. p, 53-54).
}

Belmiro Braga foi seguido por Primo Alfredo que o apresentou ao crítico Sílvio Romero; Primo Nélson que o ensinou sobre Tolstoi e cedo lhe transmitiu o "vírus da literatura" e o professor Almeida Queirós, que o iniciou na literatura, mostrando ao menino os escritores franceses. Com esses mentores, a criança conheceu desde muito cedo grandes nomes da literatura universal, fato que possibilitou sua formação como poeta. Assim como o 
menino descrito nas memórias de Graciliano Ramos, Murilo fica cada vez mais fascinado pela literatura e almeja sempre ter acesso aos livros e conhecer cada vez mais obras literárias.

Mais acentuado do que em Infância são os amores infantis e adolescentes pelos quais passa o menino Murilo: Analu, a primeira menina mencionada na obra; Lili, com a qual iniciou sua formação sexual; Cláudia, que influenciou o seu processo de leitura intelectual; Marguí, motivo pelo qual se matriculou na Escola de Farmácia, somente para ficar perto dela; Adelaide, harpista que o "acendia"; Carmem, sua prima por quem sentia simultaneamente atração e repulsa e Teresa, por quem, no início da adolescência, passou a sentir uma forte inclinação erótica.

Enquanto os homens apresentados nas memórias são responsáveis pelo desenvolvimento intelectual do menino, essas moças, com quem teve um relacionamento e as demais descritas na obra, pelas quais ele apenas se encanta, segundo Marília Rotier Cardoso, influenciam em larga escala o seu processo criativo:

\begin{abstract}
São as figuras de mulher que lhe comunicam energia vital e sensibilidade artística. Por isso mesmo, "tudo principiou com Etelvina, ama de leite dos meninos mais velhos", mas é "nos peitos de Sebastiana", junto às histórias de fada, que se preserva sua infância. Os signos entrelaçados de aconchego, desejo e percepção do belo, transmitidos por esses corpos negros ao corpo do menino, multiplicam-se nos gestos de Adelaide, a tocadora de harpa, na imagem cinematográfica de Asta Nielsen, nas muitas namoradas juiz-foranas e vão concentrar-se nas mulheres - filhas, hóspedes, criadas - que habitam o sobradão festivo de Prima Leonor. (...). Foi deixando-se perder nos labirintos do sobrado que o Murilo criança acumulou visões preciosas para suas construções poéticas (...). A beleza desconcertante do corpo feminino (...) transcende esse instante iluminador para fixar-se em metáfora de variados usos, configurando, assim, o mecanismo preciso e mágico que produz a poesia. (CARDOSO, 2003, p. 8-9).
\end{abstract}

Nessa obra, podemos perceber como funcionava a sociedade da época e quais os lugares que uma criança frequentava naquela cidade, tais como o cinema, o circo e as festas de carnaval, que nos ajudam a reconstituir a infância vivida por esse menino, o qual, ainda pequeno, já tinha uma vida social de intensa atividade e podia se relacionar com diferentes pessoas, não apenas da sua faixa etária.

No último capítulo de seu texto memorialístico, como uma espécie de conclusão, Murilo Mendes se caracteriza como um menino de "olho precoce" que era movido pela curiosidade:

O prazer, a sabedoria de ver, chegavam a justificar minha existência. Uma curiosidade inextinguível pelas formas me assaltava e me assalta sempre. Ver coisas, ver pessoas na sua diversidade, ver, rever, ver, rever. $\mathrm{O}$ olho armado me dava e me dá força para a vida. (MENDES, 2003. p. 178). 
Assim, a criança tem um enorme fascínio pelos lugares distantes do mundo, bem como interesse pelas mulheres dessas localidades. Esse menino curioso se assemelha com a curiosidade presente na autobiografia de Graciliano, na qual temos também uma criança bastante interessada em conhecer e aprender mais sobre o funcionamento do mundo ao seu redor, apesar de nem sempre obter as respostas para suas indagações.

Assim, podemos perceber que o menino de A Idade do Serrote vive uma infância feliz, sem maiores atropelos, sem sofrer nenhum tipo de trauma que pudesse ter marcado o restante de sua vida, pelo contrário, o autor evidencia que apenas aspectos positivos, como a educação religiosa que recebeu do pai, as meninas que namorou, as mulheres com quem teve contato, os homens que o auxiliaram no processo de leitura e fizeram com que se interessasse por Literatura, foram determinantes para o sujeito que se tornou, como também para a sua formação como intelectual e poeta.

Diferentemente do que ocorre com o passado reconstruído por Graciliano Ramos, no qual vemos uma criança reprimida que sofre com a falta de afeto dos pais e com a péssima educação recebida na escola, que marcam profundamente o menino, os quais o influenciam por toda a infância chegando até a sua vida adulta, a infância elaborada por Murilo Mendes é repleta de imagens alegres, dando a entender ao seu leitor que esse menino viveu os primeiros anos de vida até o início da adolescência de forma tranquila e sem problemas de relacionamento com os pais e demais membros da família.

Por fim, a imagem que o autobiógrafo mineiro constrói da sua infância é a de um menino curioso, que passa por inúmeras experiências na infância, tendo acesso por meio delas a um variado conhecimento cultural, que contribui para o seu trabalho poético:

\footnotetext{
Assim é que o adulto, artista reconhecido, nos meados dos anos sessenta, deseja fixar seu retrato de criança. Dono de uma enorme vontade de conhecer, exercita-se como voyeur e visionário, nos lugares mais diversos: o quintal da casa paterna, a escola, a missa de domingo, ou a calçada da rua Halfeld. As imagens que gravou, retomadas décadas depois, devem guardar a precocidade do momento em que foram captadas. Seu propósito é revelar a arte poética, norteadora de sua obra, construída sob o signo do extemporâneo, para abarcar a durée inconsciente e a dimensão eterna da fé cristã. (CARDOSO, 2003. p. 7).
}

Dessa forma, Murilo Mendes com sua autobiografia, teve a intenção de recriar determinados momentos de sua vida, elaborando o seu passado de tal forma que tais períodos sejam vistos como decisivos para a sua carreira de poeta, como também para o estilo escolhido por ele para compor os seus poemas. 
Quando o "olho precoce" encontra a "cabra-cega": semelhanças entre Infância e $A$ Idade do Serrote

Apesar de apresentarem algumas diferenças estruturais e de conteúdo e dos vinte e quatro anos que separam uma publicação da outra, as autobiografias de Graciliano Ramos e Murilo Mendes têm algumas semelhanças entre si.

As duas obras possuem um texto fragmentado. Em Infância, alguns capítulos foram publicados primeiramente em periódicos e somente depois foram reunidos e publicados em formato livro, organizados sob uma tênue linearidade. Sendo assim, esses capítulos têm certa independência uns dos outros. Além disso, a fragmentação também se dá por meio do embate com a memória, pois apresenta lembranças extremamente confusas que vão se desanuviando no decorrer da narrativa.

Em A Idade do Serrote, a fragmentação também aparece, mas em um grau muito maior do que na autobiografia de Graciliano. Também possui uma leve linearidade, com citações de tempo bastante esporádicas, que impossibilitam determinar com precisão qual a idade do menino em cada uma das situações que vivenciou. Além disso, em função dos aspectos verificados por Candido, que já mencionamos, o tema-variação, a mudança frequente de estilo e o uso sistemático do insólito, contribuem ainda mais para a característica fragmentária dessas memórias.

Outro aspecto semelhante em ambas as obras e que já salientamos é a presença da curiosidade. Os dois meninos são descritos como bastante curiosos, sempre em busca de informações sobre aquilo que desconhecem, mesmo que nem sempre obtenham as respostas que gostariam, como é o caso do menino Graciliano.

Essas duas obras também fazem uso da mesma estratégia de construção do eu, o uso de perfis de personagens. Graciliano conta a história de vida de pessoas que compuseram sua infância, tais como: o padre João Inácio, o moleque José, D. Maria, Chico Brabo, Fernando, Jerônimo Barreto, entre outros. Murilo, por sua vez, menciona as histórias de Etelvina, Sebastiana, Amanajós, Belmiro Braga, Sinhá Leonor, o professor Aguiar, etc. Nessas duas memórias, ao descreverem tais personagens, estão, ao mesmo tempo compondo o próprio eu. Ou seja, ao construírem esses perfis, estão também construindo a sua própria formação, além de inserirem na definição dessas pessoas, a visão da criança a respeito delas.

A essas similaridades se une também o saque ao arquivo europeu, proposto por Molloy, o qual está presente nesses livros. Na autobiografia de Graciliano Ramos, por 
exemplo, ao falar de uma criança da escola, faz uso de um personagem literário, a imagem do gigante Adamastor:

Ele suportava a ingratidão e os remoques, desvanecia-os depressa, ria mostrando os dentes amarelos, que me faziam pensar no gigante Adamastor. À minha entrada na escola, o sujeitinho me surgira de cotovelos fincados nas pernas, gaguejando áspero e rouco (...). A lembrança motivara a associação. Era realmente pálido e medonho. (RAMOS, 1975. p. 245).

Murilo Mendes também recorre ao arquivo europeu, mas de uma maneira bastante peculiar, usando frases ou escritores europeus como forma de ratificar seu discurso. Um exemplo disso se dá quando ele menciona a presença do circo na cidade e a sua atenção se volta para o leão Marruzko. Ao descrevê-lo, serve-se de diversas imagens que outros escritores já elaboraram sobre o leão, como os versos de Victor Hugo, Mário de Sá-Carneiro, Teixeira de Pascoaes e Jean Arp. (cf. MENDES, 2003. p. 45-46).

Essa estratégia nos mostra que esses autores pretenderam construir suas memórias, tendo como base também a memória dos outros, como se as suas lembranças fossem formadas com as lembranças dos outros. Assim, percebemos que essas obras, apesar de aparentemente muito diferenciadas, apresentam, na realidade, muitas semelhanças, pois se aproximam não somente por meio de aspectos relativos à forma, mas também se relacionam por similaridades de conteúdo.

\section{Considerações Finais}

As autobiografias surgiram no século XVIII como resultado da subjetividade do sujeito que vinha se construindo desde o século XVI. Desse momento para o século XX, muitos textos memorialísticos foram escritos, que seguiam a retórica clássica desse gênero, elaborada a partir das Confissões de Rousseau. Outras obras, porém, desobedeceram tal retórica, inserindo nela novas formas de autorreflexão e autorreferenciação.

De modo geral, em uma autobiografia, o autor elabora o seu passado, reconstituindoo de acordo com o indivíduo que se tornou no momento presente da escrita. Dessa forma, o passado é um produto continuamente inacabado, pois depende tanto do que está acontecendo com o sujeito no período atual, como também quais são as suas expectativas em relação ao futuro.

Sendo assim, nas autobiografias em questão - Infância, de Graciliano Ramos e A Idade do Serrote, de Murilo Mendes - o passado foi contado sob a perspectiva do presente 
da escrita, isto é, a imagem dos primeiros anos de vida de tais escritores é construída, não como de fato aconteceu, mas a partir das intenções deles sobre como gostariam que a sua infância fosse vista por seus leitores.

Então, apesar de mostrarem infâncias diferentes - Graciliano Ramos apresenta uma criança oprimida pelos pais e escola, enquanto que Murilo Mendes expõe um menino que tem uma infância feliz, com o afeto dos pais e o apoio de mentores no seu processo de aprendizagem de leitura - tais autores possuem objetivos semelhantes, ambos querem dar ênfase que os acontecimentos relatados em suas memórias de quando eram crianças estão presentes ali devido a sua importância para a formação deles como intelectuais e escritores de textos literários.

\section{Referências}

ARFUCH, Leonor. O espaço biográfico: mapa do território. In: Dilemas da subjetividade contemporânea. Rio de Janeiro: EDUERJ, 2010.

O Espaço Biográfico.

CANDIDO, Antonio. Ficção e Confissão: Ensaios sobre Graciliano Ramos. 3 ed. Rio de Janeiro: Ouro sobre Azul, 2006.

. Poesia e Ficção na Autobiografia. In: . A Educação pela Noite e outros ensaios. São Paulo: Ática, 1987.

CARDOSO, Marília Rotier. Prefácio. In: MENDES, Murilo. A Idade do Serrote. Rio de Janeiro: Record, 2003.

DUQUE-ESTRADA, Elizabeth Muylaert. Montaigne, Rousseau e Barthes. In: Devires Autobiográficos. A Atualidade da escrita de si. Rio de Janeiro: NAU/ Editora PUC/Rio, 2009.

MENDES, Murilo. A Idade do Serrote. Rio de Janeiro: Record, 2003.

MOLLOY, Silvia. Vale o Escrito. A Escrita Autobiográfica na América Hispânica. Chapecó: Argos, 2003

NITSCHACK, Horst. A Escrita Autobiográfica de Graciliano Ramos: buscando o espaço da subjetividade. In: GALLE, Helmult et al (Org.). Em primeira pessoa. Abordagens de uma teoria da autobiografia. São Paulo: Annablume; Fapesp; FFLCH, USP, 2009.

RAMOS, Graciliano. Infância. 10.ed. Rio de Janeiro: Record., 1975.

STRAUB, Jürgen. Memória Autobiográfica e Identidade Pessoal. Considerações Históricoculturais, comparativas e sistemáticas sob a ótica da psicologia narrativa. In: GALLE, Helmult et al (Org.). Em Primeira Pessoa. Abordagens de uma teoria da autobiografia. São Paulo: Annablume; Fapesp; FFLCH, USP, 2009. 
ZAGURY, Eliane. A Infância Revivida. In: . A Escrita do Eu. Rio de Janeiro:

Civilização Brasileira; Brasília: INL, 1982.

[Recebido em julho de 2012 e aceito para publicação em outubro de 2012]

\section{The Written Childhood in Graciliano Ramos and Murilo Mendes}

Abstract: Since the nineteenth century, the Brazilian writers of literary texts devoted to record the events of their life in autobiographies. This practice has intensified in the first half of the twentieth century, when many modernist authors wrote their memoirs. Among these writers stand out Graciliano Ramos (1892-1953) and Murilo Mendes (1901-1975), whose reported the events of their early life in Infância (1945) and A Idade do Serrote (1969), respectively, emphasizing their relationship with parents, the experiences of literacy and learning to read, and also their training as readers. This paper therefore aims at comparing these two works, seeing how these authors made use of recurring elements in classic autobiography, as well as checking the image of childhood that these autobiographers developed with a view from studies by Silvia Molloy (2003) and Jürgen Straub (2009) on the reconstruction of past autobiographical texts.

Keywords: Childhood. Development of the Past. Autobiography.

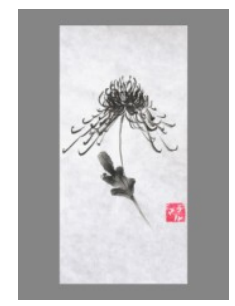

